Prepared in cooperation with the Kansas Water Office, Kansas Department of Health and Environment, The Nature Conservancy, City of Topeka, Johnson County WaterOne, City of Manhattan, and City of Olathe

\title{
Dye-Tracing Plan for Verifying the Kansas River Time-of-Travel Model
}

Open-File Report 2020-1039 



\section{Dye-Tracing Plan for Verifying the Kansas River Time-of-Travel Model}

By Chantelle A. Davis, Bradley S. Lukasz, and Madison R. May

Prepared in cooperation with the Kansas Water Office, Kansas Department of Health and Environment, The Nature Conservancy, City of Topeka, Johnson County WaterOne, City of Manhattan, and City of Olathe

Open-File Report 2020-1039 


\title{
U.S. Department of the Interior \\ DAVID BERNHARDT, Secretary
}

\author{
U.S. Geological Survey \\ James F. Reilly II, Director
}

U.S. Geological Survey, Reston, Virginia: 2020

For more information on the USGS - the Federal source for science about the Earth, its natural and living resources, natural hazards, and the environment—visit https://www.usgs.gov or call 1-888-ASK-USGS.

For an overview of USGS information products, including maps, imagery, and publications, visit https://store.usgs.gov/.

Any use of trade, firm, or product names is for descriptive purposes only and does not imply endorsement by the U.S. Government.

Although this information product, for the most part, is in the public domain, it also may contain copyrighted materials as noted in the text. Permission to reproduce copyrighted items must be secured from the copyright owner.

Suggested citation:

Davis, C.A., Lukasz, B.S., and May, M.R., 2020, Dye-tracing plan for verifying the Kansas River time-of-travel model: U.S. Geological Survey Open-File Report 2020-1039, 10 p., https://doi.org/10.3133/ofr20201039.

ISSN 2331-1258 (online) 


\section{Contents}

Abstract

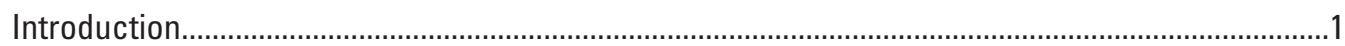

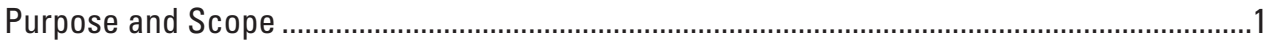

Description of Study Area ...............................................................................................

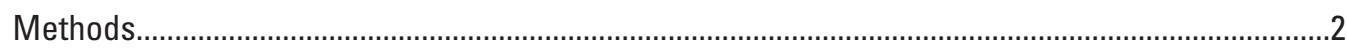

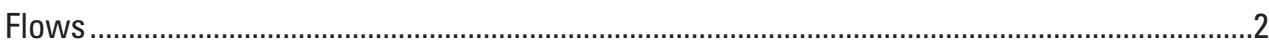

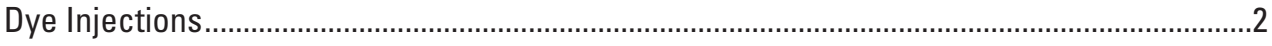

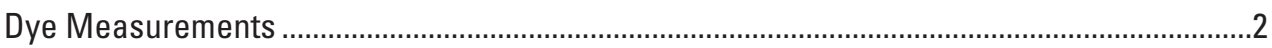

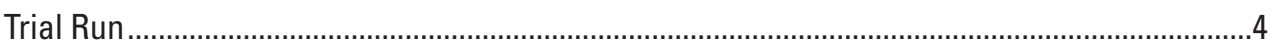

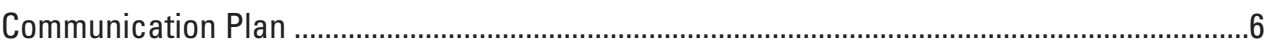

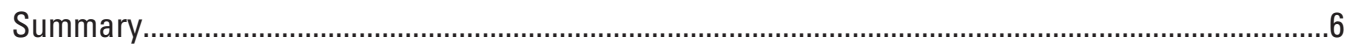

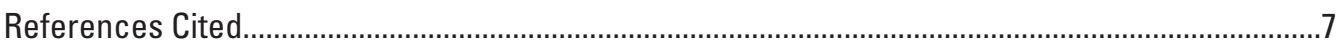

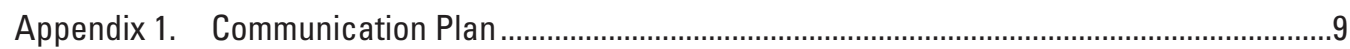

\section{Figures}

1. Map showing the study area, lower Kansas River, northeastern Kansas ..........................3

2. Graph showing a typical time-concentration curve for the movement of dye past a fixed measurement point downstream from a dye injection...

\section{Tables}

1. Planned injection amounts of rhodamine water-tracing dye at each injection site and the predicted rhodamine water-tracing dye concentrations per downstream monitoring location for a streamflow near 2,000 cubic feet per second, Kansas River, northeastern Kansas....

2. Planned injection amounts of rhodamine water-tracing dye at each injection site and the predicted rhodamine water-tracing dye concentrations per downstream monitoring location for a streamflow near 5,000 cubic feet per second, Kansas River, northeastern Kansas

3. Planned injection amounts of rhodamine water-tracing dye at each injection site and the predicted rhodamine water-tracing dye concentrations per downstream monitoring location for a streamflow near 10,000 cubic feet per second, Kansas River, northeastern Kansas. 


\section{Conversion Factors}

U.S. customary units to International System of Units

\begin{tabular}{lcl}
\hline \multicolumn{1}{c}{ Multiply } & By & \multicolumn{1}{c}{ To obtain } \\
\hline mile $(\mathrm{mi})$ & Length & \\
\hline \multicolumn{3}{c}{ Area } \\
\hline square mile $\left(\mathrm{mi}^{2}\right)$ & 259.0 & kilometer $(\mathrm{km})$ \\
square mile $\left(\mathrm{mi}^{2}\right)$ & 2.590 & square kilometer $\left(\mathrm{km}^{2}\right)$ \\
\hline & Flow rate & \\
\hline cubic foot per second $(\mathrm{ft} 3 / \mathrm{s})$ & 0.02832 & cubic meter per second $\left(\mathrm{m}^{3} / \mathrm{s}\right)$ \\
\hline
\end{tabular}

\section{Datum}

Vertical coordinate information is referenced to the North American Vertical Datum of 1988 (NAVD 88).

Horizontal coordinate information is referenced to the North American Datum of 1983 (NAD 83).

\section{Supplemental Information}

Rhodamine water-tracing (RWT) dye concentrations are given in micrograms per liter ( $\mu \mathrm{g} / \mathrm{L})$, and RWT dye injection amounts are given in liters (L). 


\title{
Dye-Tracing Plan for Verifying the Kansas River Time-of-Travel Model
}

\author{
By Chantelle A. Davis, Bradley S. Lukasz, and Madison R. May
}

\begin{abstract}
The Kansas River provides drinking water for multiple cities in northeastern Kansas and is used for recreational purposes. Thus, improving the scientific knowledge of streamflow velocities and traveltimes will greatly aid in water-treatment plans and response to critical events and threats to water supplies. Dye-tracer studies are usually done to enhance knowledge of transport characteristics, which include streamflow velocities, traveltimes, and dispersion rates, within a river system. To achieve this in the Kansas River, rhodamine water-tracing dye is planned to be injected into the Kansas River during three different flow ranges at three locations: Manhattan, Topeka, and Eudora. The primary purpose of doing a dye-tracer study in the Kansas River is to calibrate a time-of-travel model used for estimating streamflow velocities and traveltimes, which can be used by the public as well as drinking water suppliers to protect water resources and publicwater supplies.
\end{abstract}

\section{Introduction}

The potential of a contaminant in the Kansas River upstream from water users is a perpetual risk. The ability to predict the length of time it will take for a contaminant to reach a specific location is needed for water-resource managers and municipal water suppliers to mitigate risk. The Kansas River provides drinking water for multiple cities in northeastern Kansas and is used for recreational activities. Knowledge of streamflow velocities and traveltimes will greatly aid in proactive adjustment of water-treatment plans and public notice of unsafe water-quality conditions. Although hydraulic models are available to estimate traveltimes and concentrations, these models require detailed information about channel and flow characteristics, lack verification data, were not designed to be used by the public, and do not use real-time streamflow data from the U.S. Geological Survey for improving time-of-travel estimates.

Regression equations were developed to estimate streamflow velocities, instream traveltimes, and contaminant concentrations as a solute disperses through a river reach
(Jobson, 1999). These equations are based on time-of-travel data from several dye-tracer studies performed throughout the United States, described in Jobson's 1999 report, that do not require site- or channel-specific data about the channel shape or roughness parameters. The regression equations (Jobson, 1999) provide additional velocity estimates (maximum probable velocity) that can provide estimates for "worst-case scenarios" where traveltimes are faster and peak concentrations are higher than expected. Models that implement regression equations from Jobson (1999) should be validated with measured velocities. Dye-tracer studies are a preferred and common method for validating such models. Multiple dye-tracer studies covering a range of discharge values can be used to validate and (or) calibrate any model developed for the Kansas River that uses regression equations to estimate traveltimes.

Although other studies (McCarthy, 2006, 2009; Whiteman, 2012) determined that equations from Jobson (1999) provide reasonable estimates of streamflow velocities used to calculate traveltimes, preliminary analyses of the Kansas River indicate traveltime discrepancies, on the basis of channel slope, between Jobson's equations and the U.S. Army Corps of Engineers, Hydrologic Engineering Center's River Analysis System transport models, necessitating further validation. Dye-tracer studies are usually used to develop or calibrate transport models for predicting instream traveltimes (Kilpatrick and Wilson, 1989). The U.S. Geological Survey in cooperation with Kansas Water Office, Kansas Department of Health and Environment, The Nature Conservancy, City of Topeka, Johnson County WaterOne, City of Manhattan, and City of Olathe developed a dye-tracing plan for verifying the Kansas River time-of-travel model.

\section{Purpose and Scope}

The purpose of this report is to detail a strategic plan for a dye-tracer study in the Kansas River using rhodamine watertracing (RWT) dye. This report can also be used to supplement any press releases or media advisories made before beginning a planned dye-tracing study in the Kansas River. 


\section{Description of Study Area}

The study area encompasses the lower Kansas River, beginning near Manhattan, Kansas, and terminating near Lake Quivira, Kans. (fig. 1). The Kansas River and its associated alluvial aquifer provide drinking water for about 800,000 people in northeastern Kansas (Graham and others, 2018). Other uses of the Kansas River include recreation, aquatic-life support, food procurement, groundwater recharge, and agricultural uses (Graham and others, 2018). Low-head dams are at Topeka, Tecumseh, and Lawrence; and near Lake Quivira. This planned study is focused on the Kansas River and does not consider the time-of-travel near the dams but rather their overall effect on the Kansas River.

\section{Methods}

The Kansas River dye-tracer study is planned to be performed at three different streamflow regimes to determine traveltimes, streamflow velocities, and longitudinal dispersion rates to calibrate and validate the time-of-travel model. Methods planned for flows, dye injections, and dye measurements are described in this section.

\section{Flows}

Three different streamflow rates are planned to be tested, which will decrease the standard error for the estimated traveltimes, to identify changes in traveltimes associated with streamflow rate. Because of the uncertainties of flow dynamics around these dams, the elevations of the dam crests were used to determine the streamflow ranges in which to perform the dye-tracer study.

Dye tracers are usually used for time-of-travel studies because the dyes are water soluble and behave in the same manner as the water in the stream (McCarthy, 2009). A measure of the movement of the tracer will, in effect, be a measure of the movement of the water particles in the stream and of its dispersion characteristics (Kilpatrick and Wilson, 1989). By continuously measuring dye-tracer concentrations downstream from the injection point, a time-concentration curve can be developed for each sampling point to define the movement of a soluble contaminant (Kilpatrick and Wilson, 1989). Theoretical characteristics of a time-concentration curve are shown in figure 2. RWT is the dye commonly used in dye-tracer studies because it is water soluble, highly detectable, strongly fluorescent, nontoxic in low concentrations, and relatively inexpensive compared to other tracers (Wilson and others, 1986). Having overlapping injection and sampling points is recommended when dealing with long traveltimes, limitations on dye concentrations at withdrawal points, tributary inflows, and (or) changes in streamflow. Having overlapping injection and sampling points allows for multiple time-concentration curves at some sites, which can enhance the knowledge of dispersion characteristics. All subreaches do not have to be injected and sampled on the same day; however, it is ideal to begin at the downstream subreach and move upstream when the downstream plume is no longer present. However, the number of injections per experimental run that will be able to take place will depend on flow conditions at the time of the injection. Typically, dye is injected at multiple streamflows to characterize velocities and dispersion rates over a range in flows to increase accuracy of model estimations. A press release or media advisory is planned to be distributed before each dye injection to notify the public.

\section{Dye Injections}

For this strategic plan, RWT dye will be injected into the Kansas River during three different streamflow ranges at three locations: Manhattan, Topeka, and Eudora, Kans. (fig. 1). Planned dye-injection amounts are presented in tables 1, 2, and 3; injection amount is based on streamflow per site using the equations presented in Jobson (1999). The Manhattan to Lecompton section is the longest reach, resulting in the higher RWT injection required to be detected at the downstream monitoring points. Conversely, Topeka and Eudora injections are for much smaller reaches and require much less RWT to be detected at the monitor locations. Each injection is planned to consist of the total amount of dye to be injected divided evenly among three equidistant points representing the cross section of the injection point. Injection at these points in the cross section is planned to happen nearly simultaneously, thereby minimizing the amount of time and distance required for the dye to become assimilated. Although RWT is a highly fluorescent dye that may temporarily make the Kansas River appear red, purple, or brown, it is harmless to people, plants, and animals at the concentrations being used in this study (Stern and others, 2001). Targeted concentrations for this study are 50 percent of the recommended concentration, which is 10 micrograms per liter (Wilson and others, 1986), or less at the municipal intakes, which are located at Topeka, Lawrence, and Lake Quivira.

\section{Dye Measurements}

The concentration of the dye will be measured downstream from the injection sites with submersible optical fluorometers. A fluorometer is an instrument that measures the luminescence of a fluorescent substance (Kilpatrick and Wilson, 1989). The fluorometers planned to be used in this study are the Turner Design's (San Jose, California) Cyclops 7F Rhodamine Dye Logger sampling instruments. The sensors can be used in an unattended Rhodamine Dye Logger (Cyclops-7), as well as in a Spot Sampling Rhodamine Dye Tracer System (handheld). These sensor types require calibration before deployment using standards of zero microgram per liter RWT and 200 micrograms per liter. The Cyclops-7 can 


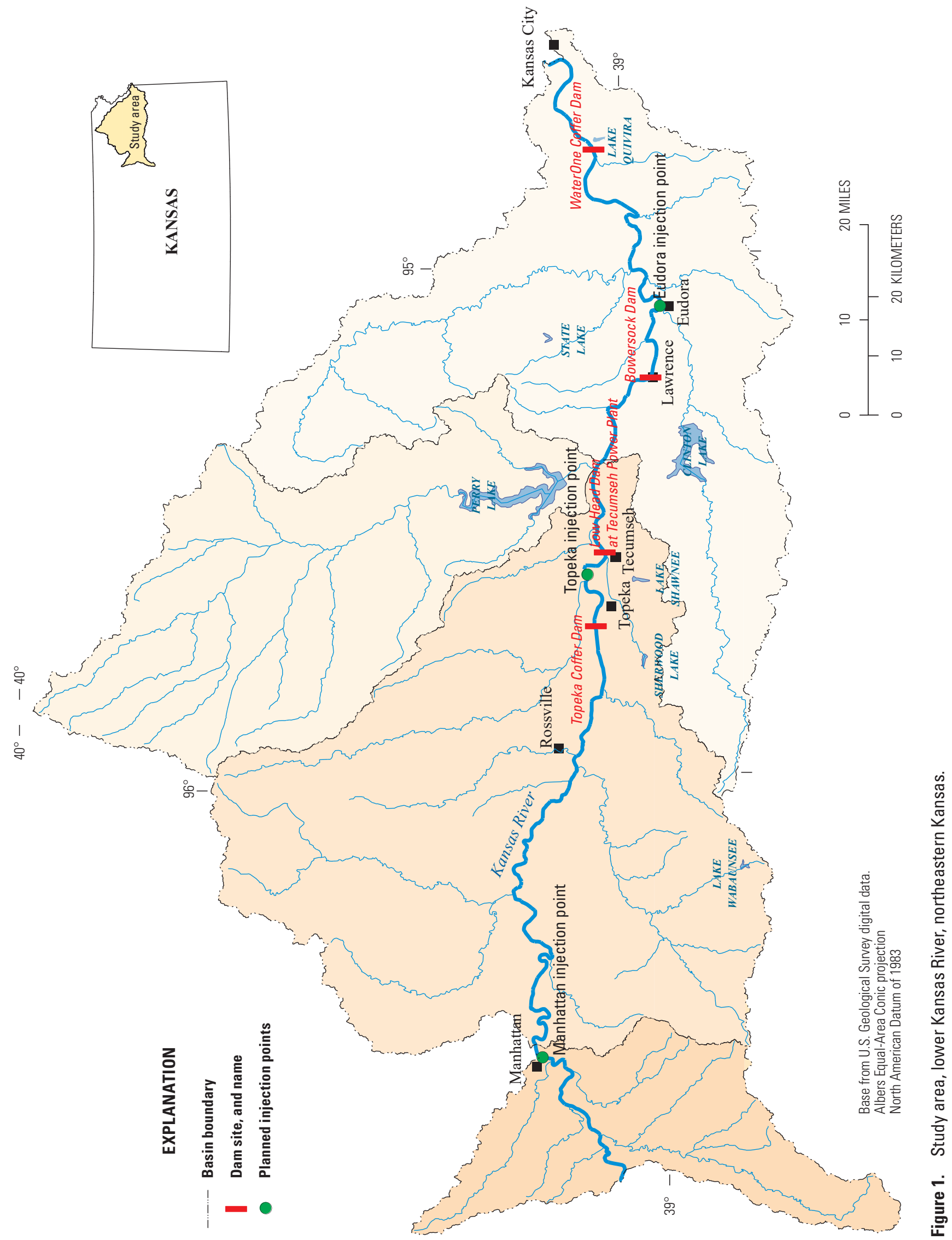




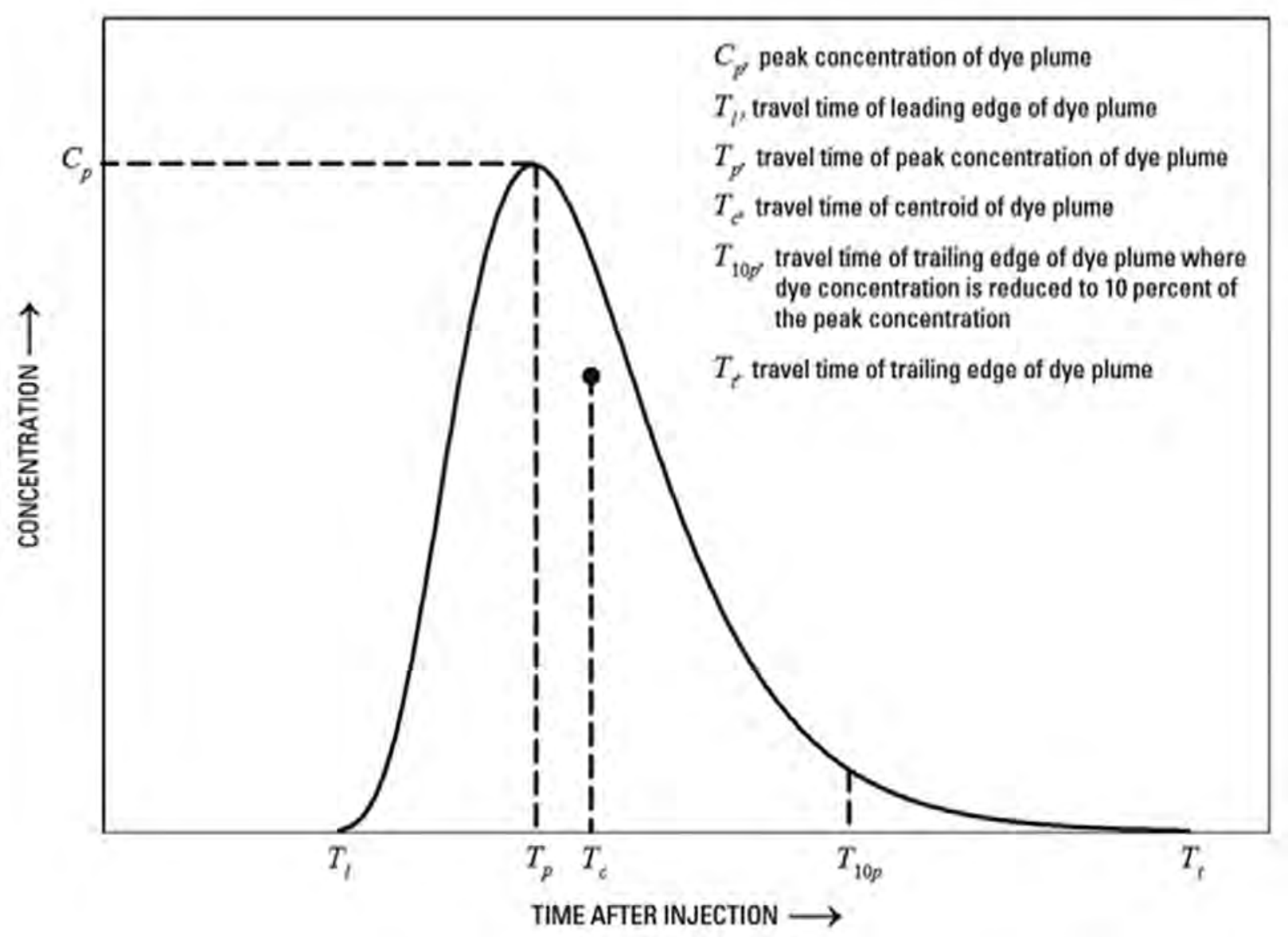

Figure 2. A typical time-concentration curve for the movement of dye past a fixed measurement point downstream from a dye injection. Modified from Kilpatrick and Wilson (1989).

collect readings at 1-minute intervals (Turner Designs, 2015), and the handhelds can be used to collect readings when the discrete samples are collected.

Fluorometers also are planned to be deployed at predetermined locations downstream from the injection sites to collect readings of fluorescence at 1-minute intervals; these collected fluorometer data will be used to determine RWT dye concentration. In addition to monitoring fluorescence using the autonomous and handheld fluorometers, discrete grab samples need to be collected and analyzed to confirm proper operation of the fluorometers. These grab samples will be collected at a targeted frequency to best capture the changing concentrations. The discrete samples will be collected using a weighted bottle sampler following methods in Rasmussen and others (2014). The grab samples will be collected from the centroid of flow and stored in coolers to avoid degradation from sunlight (McCarthy, 2009). The samples will be analyzed in nearreal time with a handheld fluorometer, as well as analyzed in the laboratory using a Turner Design-700 benchtop fluorometer, using the standard method for RWT analysis (Turner Designs, 1998). Readings taken in the field using the handheld fluorometers will be compared with predicted concentrations, thereby indicating if concentrations are to exceed the values described in tables $1-3$. If the real-time concentration readings are higher than predicted, public-water suppliers who may be affected will be contacted based on the communication plan (appendix 1). Laboratory analysis is necessary to determine RWT concentrations to a higher degree of precision than is measurable using the handheld fluorometers.

\section{Trial Run}

Before the planned full-scale injections described in tables 1-3 are done, a trial run is planned in the reach of the Kansas River from Eudora to Lake Quivira. The Eudora to Lake Quivira reach was selected for the trial run because of the flexibility of the municipal water plant, WaterOne, to adjust their intake source. The purpose of the trial run is to follow methods described in this report and determine the minimum number of sensor locations necessary in a cross section for obtaining a representative reading of RWT dye. Additional data collected during the trial run can be used to determine the lower limit of detection of RWT dye in the stream, which may allow for a decrease in the planned RWT dye injection amounts. During the trial run, more sensors are planned to be 
Table 1. Planned injection amounts of rhodamine water-tracing dye (at 20-percent stock solution) at each injection site and the predicted rhodamine water-tracing dye concentrations per downstream monitoring location for a streamflow near 2,000 cubic feet per second, Kansas River, northeastern Kansas.

[RWT, rhodamine water-tracing]

\begin{tabular}{|c|c|c|c|c|c|}
\hline $\begin{array}{l}\text { RWT dye injection } \\
\text { point and amount }\end{array}$ & Downstream monitoring location & $\begin{array}{l}\text { Predicted peak RWT } \\
\text { dye concentration, } \\
\text { in micrograms per liter }\end{array}$ & $\begin{array}{l}\text { Time to leading } \\
\text { edge of RWT plume, } \\
\text { in hours }\end{array}$ & $\begin{array}{l}\text { Time to peak } \\
\text { of RWT plume, } \\
\text { in hours }\end{array}$ & $\begin{array}{l}\text { Time to RWT } \\
\text { trailing edge, } \\
\text { in hours }\end{array}$ \\
\hline \multirow{6}{*}{$\begin{array}{l}\text { Manhattan, Kansas, } \\
6.5 \text { liters }\end{array}$} & Wamego, Kansas & 14.32 & 13.2 & 14.9 & 19.3 \\
\hline & Belvue, Kansas & 8.80 & 20.9 & 23.5 & 29.8 \\
\hline & Rossville, Kansas & 6.21 & 30.4 & 34.1 & 42.2 \\
\hline & Topeka, Kansas-Highway 75 & 4.91 & 38.8 & 43.6 & 53.3 \\
\hline & Topeka, Kansas-K-4 Highway & 4.27 & 43.5 & 48.9 & 59.3 \\
\hline & Lecompton, Kansas & 3.32 & 53.9 & 60.6 & 73.5 \\
\hline \multirow{2}{*}{$\begin{array}{l}\text { Topeka, Kansas, } \\
3.5 \text { liters }\end{array}$} & Lecompton, Kansas & 7.00 & 10.4 & 11.7 & 15.4 \\
\hline & Lawrence, Kansas-Bowersock Dam & 4.27 & 18.3 & 20.6 & 26.3 \\
\hline
\end{tabular}

Table 2. Planned injection amounts of rhodamine water-tracing dye (at 20-percent stock solution) at each injection site and the predicted rhodamine water-tracing dye concentrations per downstream monitoring location for a streamflow near 5,000 cubic feet per second, Kansas River, northeastern Kansas.

[RWT, rhodamine water-tracing]

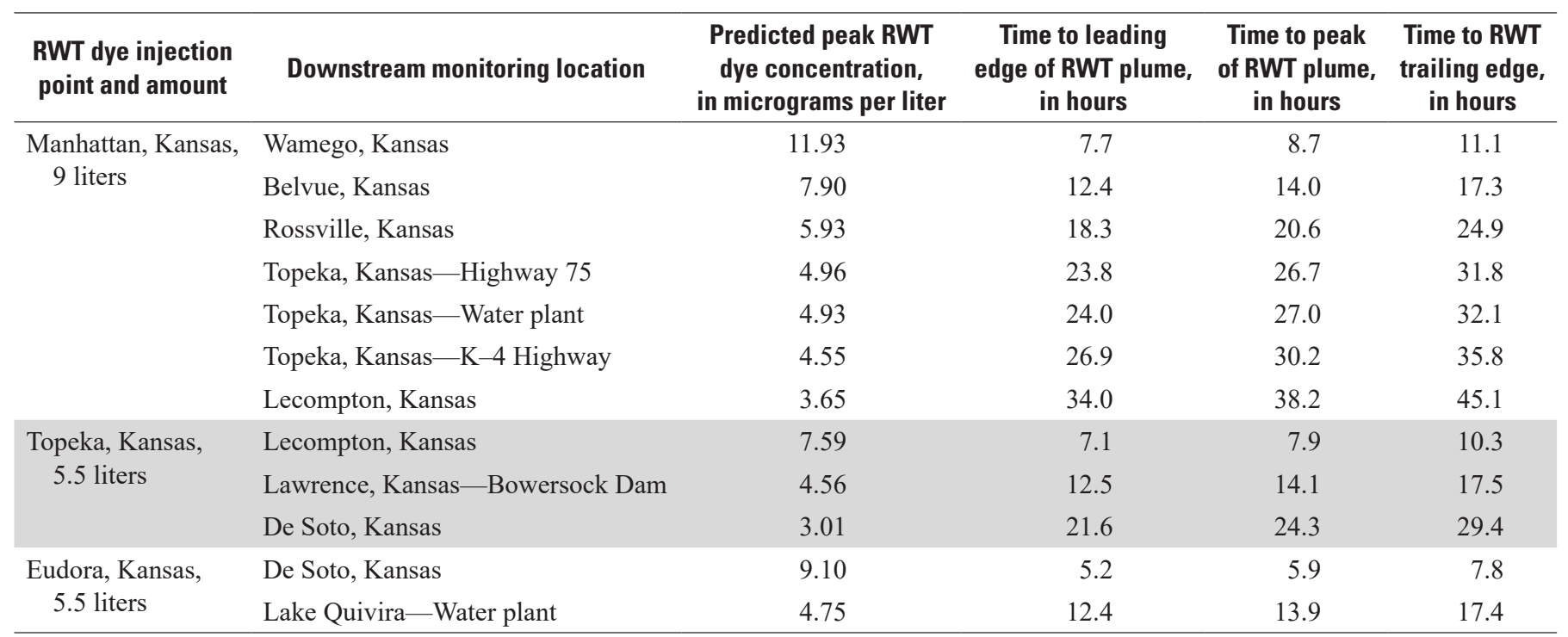


Table 3. Planned injection amounts of rhodamine water-tracing dye (at 20-percent stock solution) at each injection site and the predicted rhodamine water-tracing dye concentrations per downstream monitoring location for a streamflow near 10,000 cubic feet per second, Kansas River, northeastern Kansas.

[RWT, rhodamine water-tracing]

\begin{tabular}{|c|c|c|c|c|c|}
\hline $\begin{array}{l}\text { RWT dye injection } \\
\text { point and amount }\end{array}$ & Downstream monitoring location & $\begin{array}{l}\text { Predicted peak RWT } \\
\text { dye concentration, } \\
\text { in micrograms per liter }\end{array}$ & $\begin{array}{l}\text { Time to leading } \\
\text { edge of RWT plume, } \\
\text { in hours }\end{array}$ & $\begin{array}{l}\text { Time to peak } \\
\text { of RWT plume, } \\
\text { in hours }\end{array}$ & $\begin{array}{c}\text { Time to RWT } \\
\text { trailing edge, } \\
\text { in hours }\end{array}$ \\
\hline \multirow{6}{*}{$\begin{array}{l}\text { Manhattan, Kansas, } \\
12 \text { liters }\end{array}$} & Wamego, Kansas & 11.76 & 5.7 & 6.5 & 8.2 \\
\hline & Belvue, Kansas & 7.96 & 9.2 & 10.4 & 12.8 \\
\hline & Rossville, Kansas & 5.95 & 13.7 & 15.4 & 18.4 \\
\hline & Topeka, Kansas-Highway 75 & 4.93 & 17.7 & 19.9 & 23.5 \\
\hline & Topeka, Kansas-K-4 Highway & 4.57 & 20.0 & 22.5 & 26.3 \\
\hline & Lecompton, Kansas & 3.66 & 25.2 & 28.3 & 32.9 \\
\hline \multirow{2}{*}{$\begin{array}{l}\text { Topeka, Kansas, } \\
7 \text { liters }\end{array}$} & Lecompton, Kansas & 6.92 & 5.1 & 5.8 & 7.5 \\
\hline & Lawrence, Kansas-Bowersock Dam & 4.54 & 9.2 & 10.3 & 12.8 \\
\hline
\end{tabular}

deployed than during the full-scale injections to verify the centroid of flow is representative of the cross section of the river, and more discrete sampling intervals also are planned to be tested. The trial run will be useful to inform possible changes in the remainder of the study on sensor placement, sampling intervals, and other factors. Plans for the trail run consist of injection of RWT dye at Eudora, monitoring at the DeSoto and Lake Quivira locations, and discrete sampling for laboratory verification of RWT dye concentrations.

\section{Communication Plan}

More than 800,000 people rely on the Kansas River for drinking water, and many industrial and agricultural companies rely on the Kansas River as well. Hence, the following communication plan has been developed. In the unlikely event that an issue arises during the study, the U.S. Geological Survey will notify the Kansas Water Office, Kansas Department of Health and Environment, The Nature Conservancy, City of Topeka, Johnson County WaterOne, City of Manhattan, and City of Olathe. The public will be notified of any issues that may be of concern. Questions or concerns can be addressed by contacting agencies in appendix 1 . In addition to close communication with cooperators, multiple press releases or media advisories are planned before each experimental run, as well as postings of information at boat ramps and other river-access points.

\section{Summary}

Dye-tracer studies are usually used to develop or calibrate transport models for predicting instream traveltimes. The U.S. Geological Survey in cooperation with Kansas Water Office, Kansas Department of Health and Environment, The Nature Conservancy, City of Topeka, Johnson County WaterOne, City of Manhattan, and City of Olathe developed a dye-tracing plan for verifying the Kansas River time-oftravel model. This study is planned to improve the scientific knowledge of streamflow velocities and traveltimes in the Kansas River and may greatly aid in water-treatment plans and response to critical events and threats to water supplies. The results of the planned dye-tracer study can be used to determine traveltimes, streamflow velocities, and longitudinal dispersion rates in the lower Kansas River. The strategic plan for this study describes how rhodamine water-tracing (RWT) dye is planned to be injected into the Kansas River during three different streamflow rates at three locations: Manhattan, Topeka, and Eudora, Kansas. The concentration of the dye will be measured at downstream locations using fluorometers and discrete sampling. RWT dye is planned for use in this study because it is water soluble, is nontoxic, and can be detected at low concentrations. U.S. Geological Survey procedures for dye tracing call for the concentration of RWT dye to be no more than 10 micrograms per liter at municipal water intakes; this study plan will adhere to those procedures. A press release or media advisory are planned to be distributed before each dye injection. 


\section{References Cited}

Graham, J.L., Foster, G.M., Williams, T.J., Mahoney, M.D., May, M.R., and Loftin, K.A., 2018, Water-quality conditions with an emphasis on cyanobacteria and associated toxins and taste-and-odor compounds in the Kansas River, Kansas, July 2012 through September 2016: U.S. Geological Survey Scientific Investigations Report 2018-5089, 55 p., accessed April 15, 2019, at https://doi.org/10.3133/sir20185089.

Jobson, H.E., 1999, Contaminants in rivers and streamsPrediction of travel time and longitudinal dispersion: Geneva, Switzerland, World Meteorological Organization Operational Hydrology Report 45, 49 p.

Kilpatrick, F.A., and Wilson, J.F., Jr., 1989, Measurement of time of travel in streams by dye tracing: U.S. Geological Survey Techniques of Water-Resources Investigations, book 3, chap. A9, 27 p., accessed April 15, 2019, at https://doi.org/10.3133/twri03A9.

McCarthy, P.M., 2006, A computer program for estimating instream travel times and concentrations of a potential contaminant in the Yellowstone River, Montana: U.S. Geological Survey Scientific Investigations Report 2006-5057, 16 p., accessed April 15, 2019, at https://doi.org/10.3133/sir20065057.

McCarthy, P.M., 2009, Travel times, streamflow velocities, and dispersion rates in the Yellowstone River, Montana: U.S. Geological Survey Scientific Investigations Report 2009-5261, 25 p., accessed April 15, 2019, at https://doi.org/10.3133/sir20095261.
Rasmussen, T.J., Bennett, T.J., Stone, M.L., Foster, G.M., Graham, J.L., and Putnam, J.E., 2014, Quality-assurance and data-management plan for water-quality activities in the Kansas Water Science Center, 2014: U.S. Geological Survey Open-File Report 2014-1233, 41 p., accessed April 15, 2019, at https://doi.org/10.3133/ofr20141233.

Stern, D.A., Khanbilvardi, R., Alair, J.C., and Richardson, W., 2001, Description of flow through a natural wetland using dye tracer tests: Ecological Engineering, v. 18, no. 2, p. 173-184, accessed April 15, 2019, at https://doi.org/ 10.1016/S0925-8574(01)00076-3.

Turner Designs, 1998, TD-700 laboratory fluorometerOperating manual (ver. 1). Turner Designs, 53 p.

Turner Designs, 2015, USB Cyclops-7 Logger user's manual: Turner Designs, $36 \mathrm{p}$.

Whiteman, A., 2012, Travel times, streamflow velocities, and dispersion rates in the Missouri River upstream from Canyon Ferry Lake, Montana: U.S. Geological Survey Scientific Investigations Report 2012-5044, revised May 2012, 20 p., accessed April 15, 2019, at https://doi.org/ $10.3133 / \operatorname{sir} 20125044$.

Wilson, J.F., Jr., Cobb, E.D., and Kilpatrick, F.A., 1986, Fluorometric procedures for dye tracing: U.S. Geological Survey Techniques of Water-Resources Investigations, book 3, chap. A12, 43 p., accessed April 15, 2019, at https://doi.org/10.3133/twri03A12. 



\section{Appendix 1. Communication Plan}

The presented communication plan (see table 1.1 and chart) offers contact information useful during the time of the dye-tracing experiment. Communication throughout the event is known to be critical for preparing the stakeholders and general public along the affected reach of the river, addressing public concerns regarding visually changing the color of the river, and presenting the benefit of such a study to the public.

Table 1.1. Communication plan.

\begin{tabular}{|c|c|c|}
\hline Person & Role & Purpose of communication \\
\hline Chantelle Davis & $\begin{array}{l}\text { Principal Investigator, } \\
\text { U.S. Geological Survey (USGS) }\end{array}$ & $\begin{array}{l}\text { Communicates the progress of the study to the project manager including readings } \\
\text { of rhodamine water-tracing (RWT) dye. }\end{array}$ \\
\hline Andy Ziegler & $\begin{array}{l}\text { USGS Kansas Water Science } \\
\text { Center Director }\end{array}$ & $\begin{array}{l}\text { Higher level questions about the overall organization that may come up during the } \\
\text { experiment. }\end{array}$ \\
\hline $\begin{array}{l}\text { Local public } \\
\text { water suppliers }\end{array}$ & $\begin{array}{l}\text { Provide safe drinking water with } \\
\text { their jurisdiction }\end{array}$ & Answer questions from the public related to their specific water treatment facilities. \\
\hline
\end{tabular}



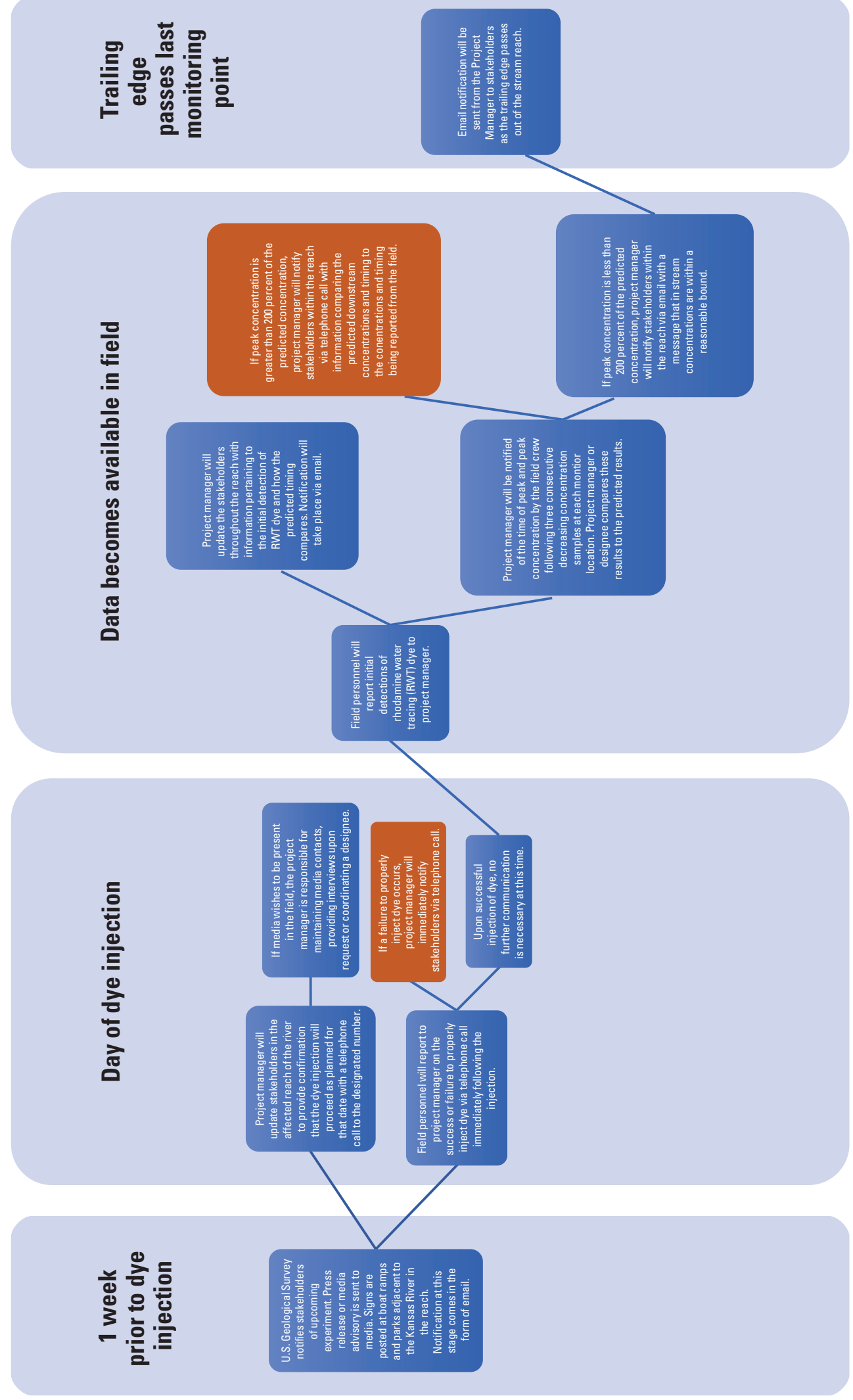

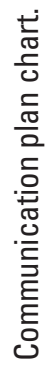


For more information about this publication, contact:

Director, USGS Kansas Water Science Center

1217 Biltmore Drive

Lawrence, KS 66049

785-842-9909

For additional information, visit: https://www.usgs.gov/centers/kswsc

Publishing support provided by the

Rolla and Pembroke Publishing Service Centers 


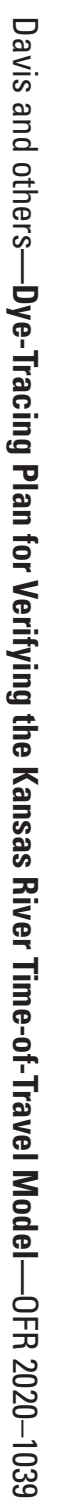

